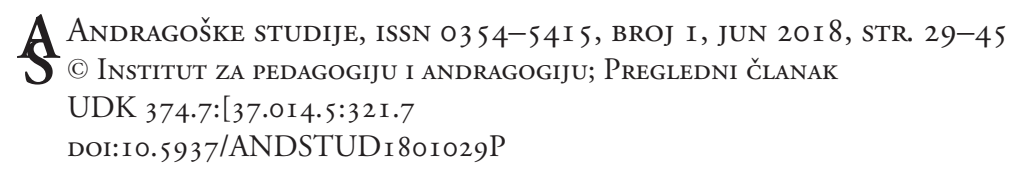

Katarina Popović ${ }^{1}$, Miomir Despotović ${ }^{2}$

Faculty of Philosophy, University of Belgrade

\title{
From Education for Democratic Citizenship to the Global Citizenship Education: On the Necessity for a Paradigm Shift ${ }^{3}$
}

\begin{abstract}
The article analyses and compares two main concepts in the field of civic education: education for democratic citizenship (EDC), prevailing in European discourse, and global citizenship education (GCE), dominant in international organisations like UNESCO. The concepts and their content are presented and analysed, and the need for the shift to the GCE is illustrated by some global tendencies and serious challenges of the global world. The responsibility to include GCE into the European concept of civic education is pointed out, as well as the challenges GCE is facing within the policy and implementation of the global agenda, SDG 4 and Education 2030.
\end{abstract}

Key words: civic education, education for democratic citizenship, global citizenship education, adult education.

\section{The purpose and functions of civic education}

Modern societies are not based exclusively on the ability of individuals to produce and create, but on their ability to manage their personal and social lives. In the era of productivism and obvious domination of economic discourse in all spheres, this might sound like a heresy. But it is certainly not, and even the simple overview of some global tendencies gives enough arguments for that. The global level

\footnotetext{
${ }^{1}$ Katarina Popović, PhD is professor at the Department of Pedagogy and Andragogy, Faculty of Philosophy, University of Belgrade, president of Adult Education Society in Serbia and Secretary General of International Council of Adult Education (katarina.popovic@outlook.com).

${ }^{2}$ Miomir Despotović, PhD is professor at the Department for Pedagogy and Andragogy, Faculty of Philosophy, University of Belgrade (mdespoto@f.bg.ac.rs).

3 This paper is part of a research project being undertaken at the Institute of Pedagogy and Andragogy, Faculty of Philosophy in Belgrade, titled "Models of assessment and strategies for improvement of quality of education" (179060), supported by the Ministry of Education, Science and Technological Development of the Republic of Serbia.
} 
and intensity of inequality, manipulation, discrimination, exploitation and the huge lack of competences of almost all single states to resist the economic and political dictate of transnational actors, are dramatic. One of the most effective ways of suppressing these tendencies is the development of a civil society, that is, the promotion of (constitutional) democracy. But democracy is a social relationship and a political system that is not established and does not develop spontaneously but must be systematically generated and nurtured. The key systemic measure in this process is the establishment of a participatory culture and a real social possibility for each individual to be a participant and co-author in the shaping, planning and improving the social life. Participatory culture implies individual participation in social relations and processes, but not the obligatory commitment of an individual to the community. Since the key for democratic culture is the integrity of an individual, a participative culture in a democratic society implies the realization of the individual's autonomy in relation to society. The basic premise for achieving this complex relationship and process is the relevant knowledge, values and abilities necessary for understanding, accepting and realizing individual civil rights, freedoms, obligations and responsibilities. From this perspective, civic education is essential for establishing and developing a society of social justice and democracy, with both active and autonomous individuals. In order to specifically emphasize the importance of critical thinking and active citizenship in solving problems in their environment, sometimes the term education for democratic citizenship is used instead of the term civic education (Djordjević \& Popović, 2008, p. 121).

This traditional view of civic education, which focuses on the training of citizens for informed and competent participation in social processes, opens up space for several crucial questions:

- what the basic function and role of civic education is - adaptation (taken in an affirmative sense) or transformation - generating micro and macro social changes;

- what the essential components of civic education are, that is, what knowledge, skills and competences should be provided;

- whether today's dramatic global changes, characterized by economic, demographic, and environmental turbulence, as well as extreme inequality, discrimination, aggression, xenophobia, racism, physical and political violence, terrorism and a brutal exploitation of natural resources require re-examining the traditional concept of civic education, and 
- if civic education, in addition to knowing and understanding the problems at national level, necessarily involves knowledge of problems on a global level and whether it should be replaced by the concept of education for global citizenship;

\section{A concept with the long past and the short history}

There is hardly a concept, paradigm or topic that is so much used, promoted and pleaded for as civic education or citizenship education, and still so unclearly defined, differently understood and interpreted. The idea itself is very old, with deep roots in the Greek philosophy and political practice of democracy, further developed through several phases of the European history of democracy, civil and human rights, with the start of the modern thinking in the French Revolution and the adoption of Déclaration des droits de l'homme et du citoyen (The Declaration of the Rights of Man and of the Citizen) passed by France's National Constituent Assembly in August 1789 - an important document, a milestone in the history of human and civil rights. But such an old idea and continuous striving throughout the century still phase some disputes in its academic understanding and definition. The question: What this concept consists of, what characteristics and skills it presumes, what its differentia specifica from the related educational areas is - these questions are still broadly debated.

\section{European understanding of Education for Democratic Citizenship}

Citizenship Education has been intensively discussed in the context of Europe and European Union, but only in the last few years the 'global aspect' has been added to the discussion, mostly due to the creation of sustainable development goals, and pushed by refugee crisis and terrorist attacks in Europe. But it did not bring order into the terminological and conceptual jungle in this field and there are still plenty of terms in use: citizenship education, education for democratic citizenship, civic education, political education, education for active citizenship... Having in mind regional differences around the globe and different understanding and usage of the same term, it becomes complicated to find a common approach, to define the strategy, develop guidelines and advocate for it. But even within Europe there are difficulties in finding a common research and policy approach. 
Karlheinz Duerr gives an overview of the main terms in use:

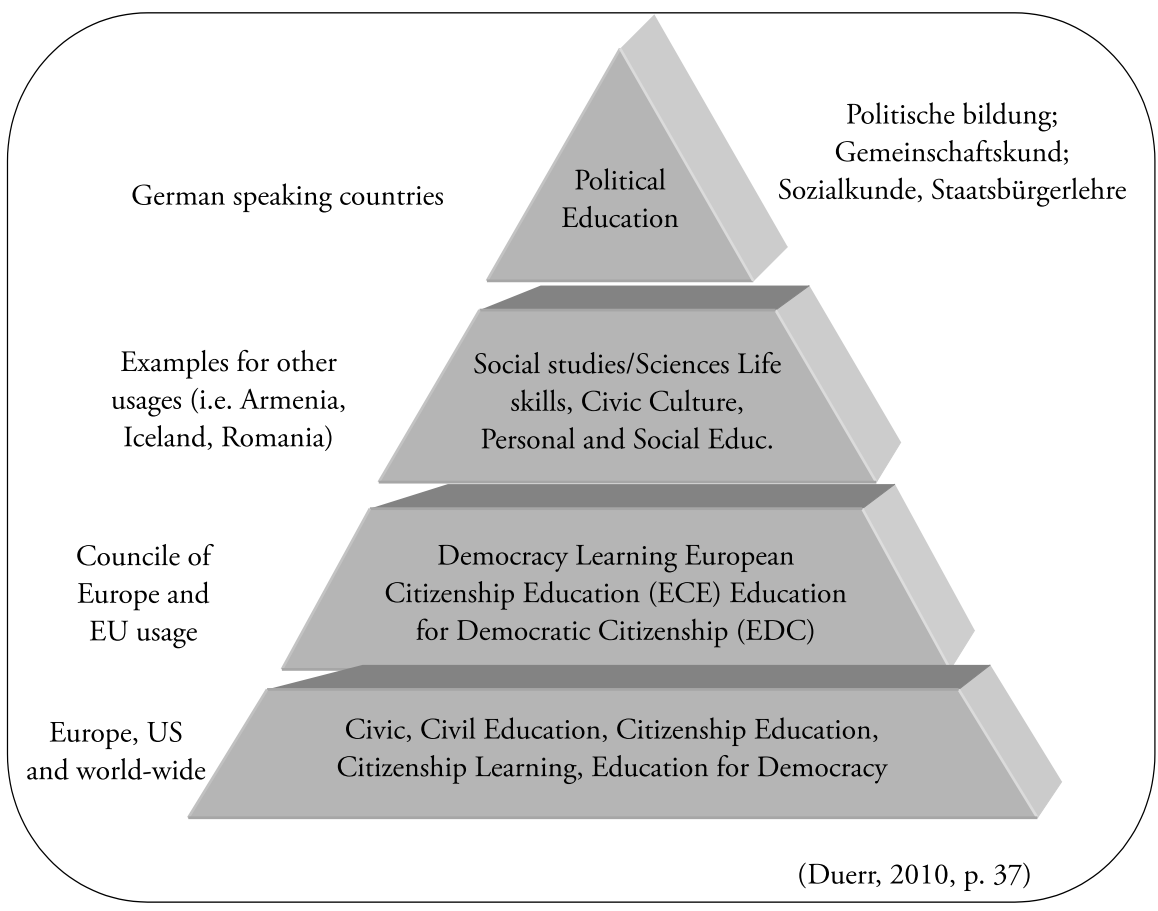

Figure 1: Civic education - main terms in use

The Council of Europe, as the main European body active in this field, gives a clear definition which connects education for democratic citizenship with Human rights education:

a) 'Education for democratic citizenship' means education, training, awareness raising, information, practices and activities which aim, by equipping learners with knowledge, skills and understanding and developing their attitudes and behaviour, to empower them to exercise and defend their democratic rights and responsibilities in society, to value diversity and to play an active part in democratic life, with a view to the promotion and protection of democracy and the rule of law. b) 'Human rights education' means education, training, awareness raising, information, practices and activities which aim, by equipping learners with knowledge, skills and understanding and developing their attitudes and behaviour, to empower 
learners to contribute to the building and defence of a universal culture of human rights in society, with a view to the promotion and protection of human rights and fundamental freedoms. (Council of Europe, 2010, pp. 5-6)

However, Council of Europe does not include areas such as intercultural education, equality education, education for sustainable development and peace education; in its view, "education for democratic citizenship focuses primarily on democratic rights and responsibilities and active participation, in relation to the civic, political, social, economic, legal and cultural spheres of society, while human rights education is concerned with the broader spectrum of human rights and fundamental freedoms in every aspect of people's lives" (Council of Europe, 2010, p. 6). So, Education for Democratic Citizenship is seen as the key instrument for the promotion of the core values of the Council of Europe: democracy, human rights and the rule of law, as well as in the prevention of human rights violations, and more and more, as a defence against the rise of violence, racism, extremism, xenophobia, discrimination and intolerance.

In 2015, European ministers had a renewed focus on Education for Democratic Citizenship, in response to the terrorist attacks in France and Denmark, reaffirming the commitment to the main values of European societies: "respect for human dignity, freedom (including freedom of expression), democracy, equality, the rule of law and respect for human rights. These values are common to the Member States in a European society in which pluralism, non-discrimination, tolerance, justice, solidarity and equality between women and men prevail." (EU, 2015 , p. 2). Paris declaration was accompanied by the financial support of 400 million euro for the projects tackling the objectives of the Paris declaration, plus 13 million for its dissemination and 14 million for the policy experimentation (European Commission, 2016, p. 1). Overview of the developments in national education policy related to the Paris Declaration (European Commission/EACEA/Eurydice, 2016) offers an impressive list of measures, initiatives and bodies. A systematic assessment of their efficiency is still pending.

In contemporary Europe, K. Duerr talks about a shift from "Education for Democratic Citizenship" to "European Union Citizenship Education" and strong focus on the processes of European integration, inclusion of post-communist societies, creation of renewed European identity etc. (Duerr, 2010, pp. 37-38, 40). This EU Citizenship education has to address the problems of the functioning of European federation, namely: new issues contained in the Lisbon Treaty (environmental protection, data security and consumer protection), European solidarity, transmitting European awareness, creation of the framework within which 
critical, participative and responsible union citizenship would be possible. "This is particularly important with view to the enormous discrepancies in wealth and economic performance which... after the enlargements of 2004 and 2006, exist in the EU. Indeed, the EU has 'discovered' Citizenship as an important tool and established a special program 'Europe for Citizens' which aims at furthering exchanges, intercultural learning, citizen networking, cultural projects etc., based on mutual tolerance and respect... Through the European Neighbourhood Policy (ENP), the EU attempts to involve all countries on the outer borders of the EU in order to create an area of democratic stability and peace." (Duerr, 2010, p. 47).

In spite of numerous projects and activities, there was a tendency of 'tiredness' with this kind of topics in Europe, and a feeling that the society is saturated with this content. The financial crises, migrant and refugee crises, terrorist attacks and others problems raised new awareness of the urgent need for new approaches and new topics in the field of civic education and related areas.

\section{Approach and understanding of Global Citizenship Education}

The global thinking about initiatives and measures that should help the world to cope with violence, wars, conflicts and hostility has also deep roots. One of the examples could be found in the ideas of great educator Jan Amos Comenius, who proposed, for the sake of permanent peaceful cooperation, establishment of few institutions: Collegium didacticum, a kind of a high school, Collegium lucis, an international 'college of light', consisting of the best scholars, and an institution devoted to the peace maintenance: "The elaborated expression of this project may be found in Comenius's major (unfinished) work De Rerum Humanarum Emendatione Consultatio Catholica. The sixth part of this General Discourse on Reform on Human Affairs, named Panorthosia (The Universal Reform), describes Comenius' ideas about 'a free common state of all mankind', a worldwide union of befriended nations where 'disputes would be solved by a peace tribunal, without wars and violence'. The main task of the reformed administration of public international affairs would be the institution and maintenance of lasting justice, order and peace. This would be pursued by an international peace court or world senate which would be furnished with great jurisdiction. It would attend not only to the maintenance of peace among states but also to the maintenance of order and justice in individual states because the two are inseparably linked. Therefore, too, the world senate would supervise national and local courts of justice and law so that their decisions and provisions would not run counter the superior, universally human principles and universal law which would derive only 
from natural law and the laws of God. Interhuman relations would be corrected through a reform of all components of public administration, involving a definition of their rights and duties relating to the social order and publicly beneficial work." (Kumpera, 1997, p. 4). With these prophetic words and ideas, Comenius seems to have announced the era of global thinking about the peace issues and the establishment of UN and UNESCO. Indeed, UNESCO is today the main promoter of these ideas, and its approach includes: Peace and human rights education, prevention of violent extremism through education, Education on the Holocaust and genocide, international understanding etc. Nowadays Global Citizenship Education (GCED) is one of the strategic areas of UNESCO's Education Sector programme for the period 2014 - 2021, based in the famous Universal Declaration of Human Rights. UNESCO's approach to GCE has the normative foundation in UNESCO's 1974 Recommendation concerning education for international understanding, co-operation, peace and education relating to human rights and fundamental freedoms. The Recommendation uses the concept of 'international education' as the forerunner of GCE, and stresses not only human rights and peace, but also justice and freedom, international understanding and co-operation, solidarity and responsibility (UNESCO, 1974, p. 148).

While GCE in European understanding points out democracy and human rights, UNESCO's approach introduces other values in the concept, taking about 'international education': " 5 .... It should develop a sense of social responsibility and of solidarity with less privileged groups and should lead to observance of the principles of equality in everyday conduct. It should also help to develop qualities, aptitudes and abilities which enable the individual to acquire a critical understanding of problems at the national and the international level; .... 6. Education should stress the inadmissibility of recourse to war for purposes of expansion, aggression and domination, or to the use of force and violence for purposes of repression, and should bring every person to understand and assume his or her responsibilities for the maintenance of peace. It should contribute to international understanding and strengthening of world peace and to the activities in the struggle against colonialism and neo-colonialism in all their forms and manifestations, and against all forms and varieties of racialism, fascism, and apartheid as well as other ideologies which breed national and racial hatred and which are contrary to the purposes of this recommendation" (UNESCO, 1974, p. 149).

Further on, UNESCO recommends that

...education should be directed both towards the eradication of conditions which perpetuate and aggravate major problems affecting human survival and well-being - inequality, injustice, international 
relations based on the use of force - and towards the measures of international co-operation likely to help solve them. Education which in this respect must necessarily be of an interdisciplinary nature should relate to such problems as: equality of rights of peoples, disarmament; the inadmissibility of using science and technology for warlike purposes, racialism and its eradication; the fight against discrimination in its various forms; ways and means of assisting developing countries; the struggle against illiteracy; the campaign against disease and famine; the fight for a better quality of life and the highest attainable standard of health; population growth, and related questions. (UNESCO, 1974, p. 150)

A different approach to citizenship is offered by another global organisation - OECD. In the context of 'rethinking human capital', OECD lists various educational outcomes beyond knowledge and skills, mentioning "moral and civic qualities - for example compassion, or the understanding of democratic institutions" (OECD, 2002, p. 119). Among other important personal characteristics are self-discipline, good decision-making skills, conscientiousness, extroversion and agreeableness. Such people contribute to the productivity but also to the overall well-being and other social benefits. (OECD, 2002, p. 123). In Education at glance 2012, OECD presents the results of the study where the levels of civic competencies were measured, among the others. The latter are defined as "knowing and understanding elements and concepts of citizenship" (issues related to civic society and systems, civic principles, civic participation and civic identities) as well as those of traditional civics, and consequently leads to supportive attitudes towards equal rights for ethnic minorities, expected electoral participation and supportive attitudes towards gender equality (OECD, 2012, pp. 205-206).

The development in the last few years brought together policy makers around common definition of sustainable development goals, their targets and indicators. UNESCO's work, as well as the initiatives, and projects of other international actors in the education for global citizenship and related areas, is nowadays guided by the Education 2030 Agenda and Framework for Action, notably Target 4.7 of the Sustainable Development Goals (SDG 4 on Education), which calls on countries to "ensure that all learners acquire the knowledge and skills needed to promote sustainable development, including, among others, through education for sustainable development and sustainable lifestyles, human rights, gender equality, promotion of a culture of peace and non-violence, global citizenship and appreciation of cultural diversity and of culture's contribution to sustainable development" (UN, 2015, p. 17). Besides democracy and human rights, 
tolerance and civic engagement, intercultural dialogue and respect for cultural, religious and linguistic diversity, social cohesion and justice (UN et al, 2015, p. 26), sustainable development is for the first time seen not as a fully separate area, but as a field that should be included in the education for global citizenship. "Global Citizenship Education (GCED) and Education for Sustainable Development (ESD) are recognized as mutually reinforcing approaches, with commonalities and specificities. Both prioritize the relevance and content of education in order to ensure that education helps build a peaceful and sustainable world. Both also emphasize the need to foster the knowledge, skills, values, attitudes and behaviours that allow individuals to take informed decisions and assume active roles locally, nationally and globally" (UN, 2017, p. 1). Many contemporary authors point out this connection - being active as citizens in the 21 st century requires more than "the ability to read a bus timetable"; it should rather grow into "...awareness of the implications of varying transport policies upon atmospheric degradation" (Clair, 2003, p. 75). The constant changes in environmental issues and the expectations that all citizens take responsibility for sustainable development are only two of the numerous reasons why adults should be provided with this segment of functional literacy in the modern world (more in: Clair, 2003; also: Orlović-Lovren and Popović, 2017).

An image of a global citizen includes, for the first time so clearly: taking care for people, planet and peace, as interconnected and equally import areas. Global crises, countries and regions in conflict (conflict and post-conflict) situations, emergency situations, social unrest and natural hazards - all these challenges require shared responsibility of global citizens. The 'traditional' competencies are still required - critical thinking, open and analytic mind, reflectiveness, tolerance, engagement etc., but they are now more connected with the high awareness about the social, political and environmental problems that modern world is confronted with - no matter in which corner of the planet people live. Some of the 'old' values and competencies gained in importance, such as critical reading of the media (especially in the 'post-true' times, where choosing the information, independent critical thinking about resources of information and unbiased, well informed decision-making become crucial). The galloping digitalisation and access to internet makes this to one of the main requirements of the modern GCE.

The work on SDG 4 and its aspects of global citizenship education are accompanied by numerous initiatives. To mention only a few: United Nations Secretary-General's Global Education First Initiative (UN SG GEFI, 2017) that was launched in September 2012 which made fostering global citizenship one of its three education priorities (p. 1); the UNESCO Week for Peace and Sustainable Development: The Role of Education and within it The UNESCO Global Forum 
on GCED, held every two years, a unique global event dedicated to key issues of GCED policy and practice (UNESCO, 2017a); GCED Clearinghouse is a global database on GCED jointly set up by UNESCO and APCEIU to facilitate information sharing and enhance knowledge and understanding of GCED (UNESCO and APCEIU, 2017); UNESCO's initiative Education as a tool to prevent violent extremism, numerous events, seminars ${ }^{4}$, publication, guidelines etc.

\section{The need to move from EDC to GCE}

The burning issues of the global world, its problems and challenges, give this area the priority character. We witness the rise of neo-nationalism and right-wing movements, both in Europe and globally, worsened by migrant crisis and the reactions to it. There is a broad shift to the right in European politics, the world has been witnessing a sharp spike in nationalist tensions, accompanied by xenophobia and nativism. There is profound political change taking place within the world's leading power, but Brexit and "trumpism" are only the symptoms of the overall development, characterised on the other end of the spectrum by religious fanatics, terrorism, and dictatorship. "People the world over are rejecting the legitimacy of liberal democracy, hardening themselves against 'enemies', retreating to the security of their tribe, and placing faith in populist leaders." (Kennedy, 2017, p. 1). This is a "reality call" to rethink the concept of global citizenship and to focus on kind of education that would address the burning problems of the modern world.

The sense of urgency that accompanies many discussions about SDGs, pointing out that "the planet can't wait", applies fully to the topics covered by GCE. And these topics are more and more common for people around the globe, in different countries and regions, not while they face the same problems (it's exactly the opposite: the gap is getting bigger), but because the responsibility is shared, global interconnectedness and interdependency is bigger and the character of main global problems calls for more than single, isolated and one-sided actions. The mentioned tendencies of increased nationalism, racism, populism and extremism require critical thinking about political, economic and social relationships and structure, but also rethinking of the main paradigm of the de-

\footnotetext{
${ }^{4} 2017$ UN Global Citizenship Education Seminar through the overview of the themes shows clearly the spectrum of topics and problems that are considered important under the GCE: Civic / Citizenship / Democracy/ Cultural literacy / Intercultural / Cross-cultural / Multi-cultural / Human rights / Human dignity / International understanding / Globalisation / International education / Interdependency / Multilingual / Bilingual / Mother tongue / Peace / Culture of peace / Social justice / Equity / Inclusive / Diversity / Sustainable development / Sustainability / Environmental (UNESCO, APCEIU, 2017).
} 
velopment and, most of all, the power relationship in the modern world. The growth-base economies and neoliberal policy and practices, extreme consumerism, neo-colonialism, huge gaps within and between countries, extreme poverty - this all requires from the modern global citizen a new kind of responsibility and questioning of our own government's policy - not only within the countries, but increasingly among the countries and continents, a more critical pedagogy and actionable postcolonial theory in education.

Civil society contributed significantly to the development of this understanding of GCE, both in concepts and practical implementations, introducing or reinforcing solidarity, empathy, responsibility, critical action etc. For example, J. Osorio writes about 'critical citizen education' and 'citizen politicisation' which manifests itself in critical pedagogy movements, and calls for the definitions of citizenship which is "not reduced to their modern western points of reference such as universality and equality but rather they expand to consider that Citizenship is a whole set of civic and ethical resources" (Osorio, 2016, p. 41). Beside the DVV International journal Adult Education and Development, ICAE (International Council for Adult Education) has organized Virtual Seminar - an intensive exchange on the topic of the journal: Global Citizenship Education. In its introduction, S. Morrison explains that:

...there can be no one theoretical understanding, rather it becomes a search for new approaches that has as its end goal tolerance and respect for all living things and having regard for sustainable development. Being connected through a 'sea of islands' also means that there is acknowledgement of a common humanity, that an action in one part of the world will still have an impact in another part of the world, therefore GCED must promote our interconnectedness and a sense of responsibility as central to relational perspectives... Boundaries and borders erected during times of imperialism contracted a world that was previously boundless, restricted natural exploration and mobility and limited access to the vast resources which were attained through mutual understanding of interdependence, cooperation and reciprocity. (ICAE, 2016, p. 5)

The Center for the Study of Social and Global Justice has developed a methodology for the critical literacy in global citizenship education, with several similar resources packs (OESD, 2006). There are numerous other organisations, initiatives, projects and publication with the broader understanding of 'citizen' 
and 'citizenship', more related to the contemporary challenges and based by critical pedagogies.

Therefore, the traditional understanding of education for democratic citizenship prevailing in Europe should increasingly include elements of global citizenship education, addressing the challenges the world is facing, and Europe is as well. The understanding of civic education which focuses on democratic participation, human and minorities rights in European societies, and problems emerging from the realm of developed Western countries is not close to sufficient. The reasons are numerous: Europe is more and more connected with other regions of the world, environmental issues and climate changes are the most obvious example of that, and the global financial crises has proved that in another way. Historical responsibility is another reason that is still very valid - colonial and imperial past is still not reflected enough and it is sometimes disguised in various forms of post colonialism, and the current circumstances and deeply rooted in that past. Further on, and most important, European politics and economy contribute to the contemporary international relationships, political tensions, global social injustice and related challenges. There are plenty of problems and issues that could be covered by the global citizenship education in the European context, including citizens responsibility to hold governments accountable and to reduce or stop harmful policies of governments and companies, such as: massive selling of arms and weapons to the countries in Middle East and to Saudi Arabia; support to autocratic, dictatorial and corrupted regimes in other regions in the world (Africa, South America, Middle East, East Europe); extensive use and exploitation of natural resources (especially in Africa) and trade agreements that are by far more beneficial for EU than for the 'Third world' countries and unjust privatisation of land and resources, including extensive illegal fishing and deforestation; extraction of billions of dollars in African resources, which are used to make the manufactured goods that are then sold back to African countries at a marked-up price; climate change and greenhouse emission, to a significant extent caused by the economies in the developed countries; vastly disproportionate use of the world's energy - water, electricity, and vastly disproportionate production of waste and Co2; tax evasion of the companies from the developed countries, and EU countries being among world's worst corporate tax havens. The stream of migrants and refugees is only an indicator, the symptom of global power architecture with deep roots. Providing help through education is an urgent and necessary task, but GCE should go a few steps further, asking the questions about the roots and causes of the problem, rising the awareness, analysing the responsibilities - asking the right questions and not only considering the consequence. Adding the right-wing and authoritarian tendencies, re-emergence of fascism, 
xenophobia, nationalism and fanaticism, we can get a full picture of the problems global citizen living in Europe is facing. Compared to that, the times when issues like common European identity, participation in practising democracy and equal rights to all minorities were central issues of civic education, seems idyllic. In less than two decades serious changes took place, new awareness has risen, new kinds of problems emerged, and global citizenship education has to address them, otherwise it will not be relevant, effective and needed.

The concept of the 'European Citizen' must now be understood as a poly-layered concept, involving the local, the regional, the national and the European dimension of citizenship - and many perceive already a growing need for discussion about global citizenship, brought about by the world-wide responsibility and need for action we face with regard to overpopulation, hunger, catastrophes, human rights violations, terrorism, fundamentalism, environment protection and climate change. (Duerr, 2010, p. 49)

\section{The challenges ahead}

The tasks set before global education are enormous, and challenges in achieving them are numerous.

Firstly one has to deal exactly with the broad spectrum of important tasks GCE should cover - such an understanding is very wide, includes a lot of knowledge, plenty of various competencies and set of important values. Achieving this might seem as an illusion, especially because each of the tasks has to do with some of the huge global problems of the modern world. But the complexity does not diminish the urgent need and importance of these tasks; it only requires more systematic research on the concept and its content, on strategic direction for further development and priority actions that need to be undertaken. There is already a lot of experience in this field - a consequent needs analysis coupled by lessons learned analysis can save time and point to the way of achieving. GCE is not aiming at changing the world, but helping people to be better prepare to take their share of responsibility for changing it.

An already observed problem is related to the missing political will to implement the target 4.7. of the SDG 4 and the global agenda, a gap between rhetoric and practice. The target 4.7. is quite vague, several important areas and 'merged' into one target, with only one indicator, which is not strong and not binding ("Indicator 4.7.1: Extent to which (i) global citizenship education and 
(ii) education for sustainable development, including gender equality and human rights, are mainstreamed at all levels in: (a) national education policies, (b) curricula, (c) teacher education and (d) student assessment" UNESCO Bangkok, 2017, p. 1). Even if the defining and measuring the achievements in this field would be extremely difficult, the adequate methodologies could be found. Another aspect shows that it is not about methodology, but about the lack of political commitment: there is a lack of funding strategy and lack of readiness to allocate the resources for GCE in spite of the powerful rhetoric around it. Having in mind that it applies to adult education too - although it is part of lifelong learning, it is the weakest link in the chain of LLL, not sufficiently recognized and dramatically underfinanced (Popović \& Koulazides, 2017, pp. 4-6) - GCE, which was and still is an important area in adult education, shares its unfavourable destiny. In welcoming the fact that the Resolution of the European council Promoting socioeconomic development and inclusiveness in the EU through education: the contribution of education and training to the European Semester 2016 stresses the importance of citizenship education, EAEA reminds of the importance of non-formal and informal learning, and in particular of adult education, and warns that "they receive too little attention in this Resolution" (EAEA, 2016, p. 1).

These are worrisome tendencies, and funding might serve as an ultimate test of the seriousness of the policy decisions and plans. In the case of GCE, its role in the global agenda is obviously not recognized and supported enough, although it is very much related to several other goals, such as poverty reduction, gender equality, responsible consumptions, peace and justice etc. The implementation of these goals without commitment to GCE and its educational means will not be possible.

Further conceptualisation, better theoretical rooting and production and use of research evidences should be continuous tasks, helping to inform policy and shape meaningful and effective actions. Civil society, as one of the main advocates, contributors and providers in the field, can play a crucial role in the dialogue about further policy creation and implementations of GCE goals and tasks.

\section{References:}

Clair, R. (2003). Words for the World: Creating Critical Environmental Literacy for Adults. In Environmental Adult Education: Ecological Learning, Theory, and Practice for Socioenvironmental Change. New Directions for Adult and Continuing Education, Vol. 2003 (99), 69-78. 
Council of Europe (2010). Council of Europe Charter on Education for Democratic Citizenship and Human Rights Education. Recommendation CM/Rec(2010)7 and explanatory memorandum. Strasbourg: Council of Europe Publishing.

Duerr, K. (2010). Citizenship Education in the Context of the European Union: A New Challenge for School and Adult Learning. Andragoške studije, 2, 35-50.

ĐorĐević, J., \& Popović, K. (2008). Obrazovanje za demokratsko građanstvo u Evropi, Andragoške studije, 1, 121-138.

EAEA. (2016). The new Resolution of the European Council stresses the importance of citizenship education. European Association for the Education of Adults. Retrieved from http://2016_eaea_statement_citizenship-education.pdf

EU. (2015). Declaration on Promoting citizenship and the common values of freedom, tolerance and non-discrimination through education. Informal meeting of European Union education ministers, Paris, 17 march 2015. Retrieved from http://cache. media.education.gouv.fr/file/01___janvier/79/4/declaration_on_promoting_citizenship_527794.pdf.

European Commission (2016). Education and radicalisation - the Paris Declaration one year on. European Commission. Retrieved from https://ec.europa.eu/education/ news/20160316-paris-declaration-education_hu.

European Commission/EACEA/Eurydice (2016). Promoting citizenship and the common values of freedom, tolerance and non-discrimination through education. Overview of education policy developments in Europe following the Paris Declaration of 17 March 2015. European Commission. Retrieved from https://webgate.ec.europa. eu/fpfis/mwikis/eurydice/images/1/14/Leaflet_Paris_Declaration.pdf

ICAE. (2016). Virtual Seminar: Global Citizenship Education. International Council for Adult Education and DVV International. Retrieved from https:/www.dvv-international.de/fileadmin/files/Inhalte_Bilder_und_Dokumente/Microsite_AED/ Sonstige_Inhalte/ICAE_virtual_seminar_2016_eng.pdf

Kennedy, M. (2017). Brexit, the rise of Trump, Colombia's rejection of Peace: It's all related. Medium. Retrieved from https://medium.com/@mkennedy721/brexitthe-rise-of-trump-colombias-rejection-of-peace-it-s-all-related-8bdb601dd673.

Kumpera, J. (1997). Tranquilla libertas - mír ve svobodě. Komenského vize mezinárodního mírového uspořádánÍ. In Kumpera, J. (red.). DĚJEPIS XVII. Sborník katedry historie. Fakulta pedagogická. Plzeň: západočeská univerzita v Plzni.

OECD. (2002). Education policy analysis 2002. Paris: OECD Publishing.

OECD. (2012). Education at a Glance 2012: OECD indicators. Paris: OECD Publishing.

OrLović, V. \& Popović, K. (2017). Lifelong learning for sustainable development - is adult education left behind? In W. L. Filho, M. Mifsud, \& P. Pace (Eds.), Handbook of Lifelong Learning for Sustainable Development (1-15). Wiesbaden: Springer.

Osorio, J.O. (2016). Citizenship in motion: an agenda for critical citizen education (towards a democratic, inclusive, close and participatory society. Education Global Research, March 2016. Retrieved from http://educacionglobalresearch.net/wpcontent/uploads/EGR09-01-Osorio-English.pdf. 
Popović, K., \& Koulaouzides, A. G. (2017). Critical Thinking, Empowerment \& Lifelong Learning Policy. In A. G. Koulaouzides, \& K. Popović (Eds). Adult Education and Lifelong Learning in Southeastern Europe. A Critical View of Policy and Practice (1-15). Rotterdam, Boston: Sense Publisher.

UN. (2015). Transforming our world: the 2030 Agenda for Sustainable Development. New York: GA United Nations.

UNESCO. (1974). Recommendation concerning education for international understanding, co-operation, peace and education relating to human rights and fundamental freedoms. UNESCO Constitution. Retrieved from http://portal.unesco.org/en/ ev.php-URL_ID=13088\&URL_DO=DO_TOPIC\&URL_SECTION=201. html

UNESCO ET AL. (2015). Incheon Declaration Education 2030: Towards inclusive and equitable quality education and lifelong learning for all. Paris: UNESCO.

UNESCO. (2017). Global Citizenship Education. Retrieved from http://en.unesco.org/ gced/approach.

UNESCO, APCEIU. (2017). The GCED Clearinghouse. Retrieved from https:// www.gcedclearinghouse.org/about and https:/www.gcedclearinghouse.org/ resources/2017-un-global-citizenship-education-seminar

UNESCO. (2017a). UNESCO Week for Peace and Sustainable Development: The Role of Education. Retrieved from http://en.unesco.org/esd-gced-week.

UNESCO BANGкок. (2017). Education for Sustainable Development and Global Citizenship in Education 2030 / SDG 4. Retrieved from http://bangkok.unesco.org/ content/education-sustainable-development-and-global-citizenship-education2030-sdg-4

UN SG GEFI. (2017). Global Education First Initiative. Retrieved from http://www.unesco.org/new/en/gefi/home/?/220.htm

UNESCO. (2017b). Education as a tool to prevent violent extremism. Retrieved from http://en.unesco.org/preventing-violent-extremism/edu-as-tool

OSDE. (2006). Critical literacy in global citizenship education. Open Spaces for Dialogue and Enquiry. Nottingham: University of Nottingham, Center for the study of social and global justice. 
Katarina Popovićs, Miomir Despotović ${ }^{6}$

Filozofski fakultet, Univerzitet u Beogradu

\section{Od obrazovanja za demokratsko građanstvo ka obrazovanju za globalno građanstvo: $\mathrm{O}$ potrebi za promenom paradigme ${ }^{7}$}

Apstrakt: Ovaj članak analizira i komparira dva glavna koncepta u oblasti građanskog obrazovanja: obrazovanje za demokratsko građanstvo (ODG), koncept koji je prevalentan u evropskom diskursu, i obrazovanje za globalno građanstvo (OGG), koje je dominantno u međunarodnim organizacijama poput UNESCO-a. Ova dva koncepta i njihov sadržaj su predstavljeni i podvrgnuti analizi, a potreba za promenom paradigme ka OGG je ilustrovana nekim od globalnih tendencija i ozbiljnih izazova globalnog društva. Istaknuta je odgovornost za uključivanje OGG-a u evropski koncept građanskog obrazovanja i naglašeni su izazovi sa kojima se OGG suočava u okviru politike i implementacije globalnog programa rada - Ciljeva Održivog Razvoja (naročito COR 4) i programa Obrazovanje 2030.

Ključne reči: građansko obrazovanje, obrazovanje za demokratsko građanstvo, obrazovanje za globalno građanstvo, obrazovanje odraslih.

\footnotetext{
${ }^{5}$ Dr Katarina Popović je vanredni profesor na Odeljenju za pedagogiju i andragogiju Filozofskog fakulteta Univerziteta u Beogradu, predsednik Društva za obrazovanje odraslih Srbije i Generalni Sekretar Međunarodnog Saveta za obrazovanje odraslih (ICAE).

${ }^{6}$ Dr Miomir Despotović je redovni profesor na Odeljenju za pedagogiju i andragogiju Filozofskog fakulteta Univerziteta u Beogradu.

${ }^{7}$ Rad je nastao u okviru projekta Instituta za pedagogiju i andragogiju (Filozofski fakultet, Beograd) „Modeli procenjivanja i strategije unapređenja kvaliteta obrazovanja“ (br. 179060), koji finansira Ministarstvo prosvete, nauke i tehnološkog razvoja Republike Srbije.
} 